\title{
Dietary protein requirements and adaptive advantages in athletes
}

\author{
Stuart M. Phillips \\ Exercise Metabolism Research Group, Department of Kinesiology, McMaster University, 1280 Main St. West, \\ Hamilton ON, Canada, L8S $4 K 1$
}

(Submitted 30 August 2011 - Final revision received 12 January 2012 - Accepted 17 February 2012)

\begin{abstract}
Dietary guidelines from a variety of sources are generally congruent that an adequate dietary protein intake for persons over the age of 19 is between $0.8-0.9 \mathrm{~g}$ protein/ $\mathrm{kg}$ body weight/ . According to the US/Canadian Dietary Reference Intakes, the RDA for protein of $0.8 \mathrm{~g}$ protein $/ \mathrm{kg} / \mathrm{d}$ is "...the average daily intake level that is sufficient to meet the nutrient requirement of nearly all $[\sim 98 \%] .$. healthy individuals..." The panel also states that "...no additional dietary protein is suggested for healthy adults undertaking resistance or endurance exercise." These recommendations are in contrast to recommendations from the US and Canadian Dietetic Association: "Protein recommendations for endurance and strength trained athletes range from 1.2 to $1.7 \mathrm{~g} / \mathrm{kg} / \mathrm{d}$." The disparity between those setting dietary protein requirements and those who might be considered to be making practical recommendations for athletes is substantial. This may reflect a situation where an adaptive advantage of protein intakes higher than recommended protein requirements exists. That population protein requirements are still based on nitrogen balance may also be a point of contention since achieving balanced nitrogen intake and excretion likely means little to an athlete who has the primary goal of exercise performance. The goal of the present review is to critically analyse evidence from both acute and chronic dietary protein-based studies in which athletic performance, or correlates thereof, have been measured. An attempt will be made to distinguish between protein requirements set by data from nitrogen balance studies, and a potential adaptive 'advantage' for athletes of dietary protein in excess of the RDA.
\end{abstract}

Key words: Amino acid: Leucine: Nitrogen balance: Carbohydrate: Performance

There is an apparent conflict between those who establish dietary protein requirements for adults ${ }^{(1)}$ and those issuing guidelines for athletes ${ }^{(2)}$. An almost global consensus is that adults need no more than $0.8-0.9 \mathrm{~g}$ protein $/ \mathrm{kg} / \mathrm{d}$ to satisfy their protein needs ${ }^{(1,3)}$. A number of recent reviews are available in which recommendations for dietary protein in athletes are assessed and scrutinized ${ }^{(2,4-8)}$. The general consensus from these reviews is that the protein needs of athletes are in general higher than those of sedentary persons. In fact, an intake of between $1.2-1.7 \mathrm{~g}$ protein $/ \mathrm{kg} / \mathrm{d}$ has been suggested as a requirement ${ }^{(2)}$. An interesting question is whether there is a middle ground between these two conflicting points of view? The goal of this review, therefore, is to provide reconciliation on the apparent disparity of opinion over whether or not athletes have elevated needs for dietary protein. Another important issue relates not to a need/ requirement for dietary protein, as it is defined by body nitrogen balance, but whether athletes could derive some benefit from additional dietary protein over and above the RDA? Finally, an important point is what intakes of protein might become excessive and a potential risk for compromising health or athletic performance?
Revision of the Canadian Recommended Nutrient Intakes (RNI) and US Recommended Dietary Allowances (RDA) to a model of nutrient adequacy and an upper limit was one base in the development of the Dietary Reference Intakes (DRI). The DRI estimates for dietary protein include an estimated average (population) requirement (EAR), a recommended dietary allowance (RDA), as well as a tolerable upper limit (UL), which is a threshold above which adverse effects of higher nutrient intakes appear to increase. In addition to the DRI recommendations for nutrient intakes there are now what are termed acceptable macronutrient distribution ranges (AMDR). The AMDR establishes a large degree of latitude in what is an acceptable partitioning of macronutrients that would, with good likelihood, meet the nutritional needs of most persons. Perhaps more importantly, the AMDR establishes that diets varying greatly in macronutrient proportion are safe and associated with good health. Of course, the specific guidelines of the AMDR provide just that, "guidelines," and clearly detail the types of fat (saturated, monounsaturated, polyunsaturated), carbohydrate (low or high glycaemic index), and protein (plant- versus animalbased). These AMDR are 45-65\% of energy from carbohydrates, $20-35 \%$ of energy from fat, and $10-35 \%$ of

*Corresponding author: S. M. Phillips, fax +905-523-6011, email phillis@mcmaster.ca, http://www.mcmaster.ca/kinesiology/grad/index.cfm 
energy from protein. Recognizing that percentages of total energy intake from macronutrients is not always the most desirable way of expressing intakes for athletes the guidelines that are perhaps more practical involve first defining carbohydrate needs as they are of paramount importance in determining athletic performance ${ }^{(9,10)}$. Thus, athletes can be categorized into 'bins' of requirement for carbohydrate depending on their training status, training volume and intensity. This would make sense considering that a skill sport athlete such as an archer would not be comparable to a marathon runner, to use examples, in terms of his or her carbohydrate needs. These 'bins' range from as low as 3-5g carbohydrate $/ \mathrm{kg} / \mathrm{d}$ for skill sport athletes who do not engage in high volumes of activity, from $5-8 \mathrm{~g}$ carbohydrate $/ \mathrm{kg} / \mathrm{d}$ for endurance and team sport athletes, and 8-10 g carbohydrate $/ \mathrm{kg} / \mathrm{d}$ for long-distance endurance athletes or those engaging in strenuous periods of training ${ }^{(9-12)}$. Having defined carbohydrate requirements, in the context of requirements for athletic performance, the decision regarding the remaining macronutrients would be how to reasonably divide them so as to provide enough essential fat in the diet with an appreciation of the source of energy and the amount of fat necessary for appropriate absorption of fatsoluble vitamins. Thus, all arguments regarding fat intake and health acknowledge that fat is generally important in the diets of athletes ${ }^{(2)}$. High-fat diets containing $>40 \%$ energy in the form of fat are, however, not recommended for athletes since they offer no advantage in exercise performance $^{(13,14)}$ and can be associated with adverse health outcomes $^{(15)}$. Thus, as it is defined within the AMDR, protein could form the remainder of food energy within the confines of $10-35 \%$ of total energy intake. Such a recommendation would 'excuse' some sports dietitians/nutritionists from advocating 'higher' protein diets, at least higher than the protein RDA, without fear of overt health consequences.

\section{Protein requirements}

The Institute of Medicine (IOM) makes the point that the RDA for protein for males and females aged 19 years or older is $0.8 \mathrm{~g}$ protein $/ \mathrm{kg} / \mathrm{d}^{(1)}$, which, using 'athletic' reference body weights of $70-90 \mathrm{~kg}$ for men and $50-70 \mathrm{~kg}$ for women, the RDA equates to $56-72 \mathrm{~g} /$ day for men and $40-56 \mathrm{~g} /$ day for women. While there is no defined tolerable UL for dietary protein (with the exception of no more than 35\% of energy coming from protein as detailed in the AMDR) or for any individual amino acid, caution was advised if the intake of specific individual amino acids would exceed that normally present in the diet from foods (see ${ }^{(1)}$ for details). Importantly, it needs to be realized that the AMDR for total protein could not truly be established. Thus, the range of protein intakes recommended in the diet was determined as the amount remaining after fat and carbohydrate needs were met. The IOM report states that "to complement the AMDRs for fat... and carbohydrate ... for adults, protein intakes may range from 10 to 35 percent of energy intake to ensure a nutritionally adequate diet." What also needs to be highlighted is the fact that the protein RDA is not established as a guideline for how much protein people should be consuming, but instead is a minimal estimate and one that is, even by the admission of those setting the protein RDA, based on a faulted method.

Part of the apparent disagreement between those deriving dietary guidelines and athletes and sports practitioners may well be the focus on the RDA, which establishes a level of protein that will replace losses and thus prevent deficiency. The methodology used in establishing the protein RDA is nitrogen balance $^{(1,16)}$. Use of nitrogen balance is an adequate method for establishing nitrogen or amino acid requirements necessary to prevent deficiency and achieve a balance of nitrogen in weight stable individuals of relatively low levels of physical activity. It is, however, possible or even likely that the same method is inadequate to establish intakes of dietary protein that are optimal for maximizing resistance training-induced gains in muscle mass and strength, and resistance or endurance training-induced adaptations in metabolic function, or preserving lean mass during periods of extreme weight loss. An interesting concept in this regard is one of the 'anabolic drive ${ }^{, 17,18)}$, in which deposition of protein during growth determines need. However, for athletes, at least in adulthood, none are growing so instead the requirement for protein would be to optimize the rate of replacement of proteins being broken down but also to optimize adaptive processes. In short, defining requirements in terms of preventing deficiency would, from an athletes' perspective, hardly be considered a position from which to frame their 'need' for dietary protein.

Nitrogen balance has long been recognized as a flawed method for determining protein needs due to a number of methodological limitations such as: i) implausibly high nitrogen balances typically observed at high protein intakes; ii) an increase in the economy of nitrogen use at low protein intakes; and iii) often estimated rather than measured dermal and miscellaneous obligatory losses of nitrogen ${ }^{(1)}$. From an athletic perspective it is also important to realize that regardless of whether or not nitrogen balance is achieved at a particular protein intake, it is possible that the level of protein consumed may be less than that required to optimize all aspects of the protein requiring processes. This point is made with the recognition that in short-term nitrogen balance studies (note that in the studies analyzed by Rand et al. ${ }^{(16)}$ the mean study duration was relatively short i.e., 10-15d), which is a period of time in which it is unlikely that adaptations in muscle, bone, and connective tissues will be captured. This is because the rates of protein turnover of proteins in bone $^{(19,20)}$, tendon ${ }^{(21)}$, and skeletal muscle tissues vary between $0.6-1 \cdot 2 \% / \mathrm{d}^{(22)}$. In contrast, the rates of protein turnover for more labile tissues are $48 \%$ /d for ileal protein synthesis ${ }^{(23,24)}$; even plasma proteins such as albumin, fibrinogen, and fibronectin have turnover rates of between $9-30 \% / d$. Thus, within the context of a 10-20d balance study the chance of detecting changes in tissue turnover in musculoskeletal tissues and their function is unlikely at best.

At marginal protein intakes nitrogen equilibrium can be attained by adaptive and potentially accommodative downregulation of amino acid requiring processes ${ }^{(25)}$, which may 
not be maladaptive/pathological in sedentary persons, but may not be optimal for an athlete. In addition, it needs to be appreciated that as individuals adapt to less than adequate protein intakes they do so by lowering nitrogen excretion $^{(16,25,26)}$ such that there is no apparent relationship between nitrogen balance and musculo skeletal tissues for reasons outlined above. An important point for athletes is that there is no relation between nitrogen balance and muscle function, which is a critical measure for athletes but one that has never been measured in the context of studies of protein adequacy. The last two points are difficult questions to assess, however, and would require long-term studies employing very intricate and revealing measures. More importantly from an athletes' perspective is the idea of whether protein intakes higher than the RDA translate into improved performance. This is an important consideration if we are to make arguments directed at optimizing physiological function based on protein intakes that would likely exceed the RDA; namely, is there benefit to consumption of protein at levels higher than the RDA and, if so, how much higher?

The choice of endpoints in studies of protein requirements also needs to be evaluated. While the attainment of nitrogen balance per se is a measurable and arguably adequate end point for sedentary persons, it is questionable whether the same can be said for athletes. For those wishing to gain lean mass, for example, positive nitrogen balance is the desired goal. This is presumably due to the periodic stimulation of muscle protein synthesis, which, if it is to support the net gain of new proteins, would require net extra amino acids; for reviews $\operatorname{see}^{(5,6,8,22)}$. For an endurance athlete the goal would likely relate to balancing the loss of leucine, an amino acid that has been shown to be oxidized to an appreciable extent during endurance exercise ${ }^{(27-31)}$, and also to support the increased protein synthesis that occurs following this form of exercise ${ }^{(32-34)}$. Thus, whatever the end outcome of any study of dietary protein needs or optimal requirements for athletes, the model may be quite different from that used by the IOM or WHO to define a protein $\mathrm{RDA}^{(1,3)}$.

A scheme for understanding how an athlete might view their 'need' for dietary protein and what 'athlete-specific' outcomes might be considered is one in which an 'optimal' protein intake rather than deficiency prevention is the goal. Regrettably, at this time it is not possible to ascertain what levels of protein would promote the necessary adaptations to support the optimal function of all protein requiring processes or optimal capacity for athletic performance.

Incongruent with the general belief of many athletes and their coaches, published position stands, and a number of viewpoints $^{(5-7)}$, evidence exists that exercise per se reduces the overall requirement for dietary protein ${ }^{(35-38)}$. The elegantly controlled studies conducted by Butterfield and her colleagues ${ }^{(37,38)}$ are often cited in support of this argument, but are criticized since the exercise intensities used in those studies do not begin to approach those that most endurance athletes regularly engage in. The implications of such criticisms are of course that more intense exercise will increase amino acid catabolism or reduce protein synthesis (i.e., the ability to retain amino acids); however, neither of these suppositions has ever been investigated.

Two longitudinal studies, in which an accrual of lean mass was observed with resistance training, showed a greater economy of nitrogen retention when the subjects consumed what was determined, through nitrogen balance, to be sufficient protein $(1.2-1.4 \mathrm{~g}$ protein $/ \mathrm{kg} / \mathrm{d})$ and energy to cover needs after a strenuous resistance training programme lasting $12 \mathrm{wk}^{(35,36)}$. It may be that the anabolic stimulus of weightlifting is enough to stimulate muscle protein synthesis such that this tissue becomes a greater site of disposal/reutilization of amino acids in both the fed and fasted states, possibly at the 'expense' of other amino acid-requiring processes. As such, these data ${ }^{(35,36)}$ may not necessarily be indicative that resistance training reduces protein requirements, but instead they may be evidence of a shift in the hierarchy of amino acid requiring processes toward a priority for muscle protein synthesis getting a 'greater share' of circulating amino acids in both the fasted and fed states. The results obtained with resistance exercise $^{(35,36)}$ may be markedly different from those seen with endurance exercise since resistance exercise is fundamentally anabolic and stimulates protein synthesis, such that loss of amino acids in the fasted state is reduced, for up to $48 \mathrm{~h}^{(39)}$. In contrast, the anabolic nature of endurance exercise is far weaker than that of resistance exercise and the improved net retention of amino acids in muscle appears to be much more transient ${ }^{(33)}$. Nonetheless, as pointed out by Millward and Jackson ${ }^{(40)}$ when the protein to energy ratio is considered, an acceptable level of protein intake in an endurance athlete does not need to be a large proportion of their energy intake to provide sufficient amino acids. It is unlikely however, that such a position represents satisfaction of a true optimal protein intake and not merely balancing of nitrogen intake and output.

\section{Protein and exercise-specific responses}

There is a large body of evidence showing that the provision of protein/amino acids supports increased rates of protein synthesis and positive protein balance following endurance exercise (for reviews see $\mathrm{s}^{(5,22,41)}$ ). These data alone provide some credence to an argument for the need for increased dietary protein for athletes above a standard requirement level. However, what is not clear in any of these studies is exactly how much of the supplemental protein is directed toward muscle protein synthesis, which goes directly to the question of how much extra protein is needed to support gains in muscle protein mass with resistance exercise or how much extra protein is required to cover oxidative protein losses in endurance athletes. Using urea tracers a number of investigations on post-exercise amino acid provision have shown no increase in urea production ${ }^{(42-46)}$, arguing that the ingested supplement is effectively and efficiently used for muscle protein synthesis and other amino acid requiring processes. Moore et $a l .{ }^{(47)}$ reported that with increasing doses of protein there was no increase in leucine oxidation until doses of $20 \mathrm{~g}$ or $40 \mathrm{~g}$ were consumed, which did not result 
in increased urea until $40 \mathrm{~g}$ of protein was consumed. These findings indicate that some protein doses exceeded a capacity, at least for leucine, for the assimilation of the amino acids into protein. On the other hand, the situation of endurance exercise is difficult to assess since in this case the stimulus is not anabolic and ultimately results in a small net accumulation of muscle contractile protein mass, at least versus the case of resistance exercise. The argument often given is that extra protein for endurance athletes is required since endurance exercise increases 'amino acid' oxidation ${ }^{(7,27,29-31,48-50)}$; however, it has never been shown, at least to this author's knowledge, that any amino acid other than leucine is oxidized to a substantial degree during exercise. Based on an average human body tissue leucine content of $590 \mu \mathrm{mol} / \mathrm{g}$ protein ${ }^{(51)}$, if $x$ amount of leucine is oxidized during an exercise bout then $x / 590$ is 'equivalent' to the number of $\mathrm{g}$ of tissue protein broken down. Such a calculation relies, however, on a number of very tenuous assumptions that are not tested in most experimental paradigms and so an increased leucine oxidation during endurance exercise may mean an increased need for dietary leucine, which unless supplements were consumed would have to come from dietary sources (especially those rich in leucine). Another important point is the recognition of the importance of dietary leucine as an amino that is more than just a substrate for protein synthesis in muscle but is also a trigger for activating protein synthesis ${ }^{(52-54)}$

In the most recent reviews of protein 'requirements' for strength training athletes it was estimated, based on a metaanalytic regression, that a daily intake of $\sim 1.33 \mathrm{~g}$ protein/ $\mathrm{kg} / \mathrm{d}$ is required for the athlete to remain in nitrogen balance $(66 \% \text { greater than the RDA })^{(5)}$. Protein 'requirements' for endurance athletes to achieve nitrogen balance, are likely somewhere around $\sim 1.2 \mathrm{~g}$ protein $/ \mathrm{kg} / \mathrm{d}^{(55)}$, but could be as high as $1.6 \mathrm{~g}$ protein $/ \mathrm{kg} / \mathrm{d}$ in individuals engaging in intense exercise $^{(7)}$. Accepting all of the shortcomings of nitrogen balance, the method used to derive the previous estimates ${ }^{(5,7)}$ is identical to the approach that was used to derive the current protein RDA; that is, an analysis of pooled nitrogen balance data from human studies ${ }^{(1,16)}$. If these estimates ${ }^{(1,16)}$ are reasonable then do these protein intakes represent an optimal level? Defining an 'optimal level' of protein intake for an athlete is something that would: i) support an athlete's ability to repair and replace any damaged proteins (due potentially to oxidative stress or mechanical disruption); ii) adaptively 'remodel' proteins in muscle, bone, tendon, and ligaments to better withstand the mechanical stress imposed by athletic training and competition; iii) maintain optimal function of all metabolic pathways in which amino acids are participatory intermediates (which includes being oxidative fuels); iv) support increments in lean mass, if desired; v) support an optimally functioning immune system; and vi) support the optimal rate of production of all plasma proteins required for optimal physiological function. If the protein 'requirements' of athletes were sufficient to support all of the aforementioned processes then the intake would not be a requirement to prevent deficiency but rather an intake that is 'optimal' and would provide an adaptive advantage for athletes. In light of this, such an intake would apparently be greater than that of a sedentary individual because the nature of exercise is such that there is an up-regulation of protein utilizing processes and, presumably, no change or an up-regulation of the processes of protein degradation and disposal. At the same time, one could argue that 'optimal' levels of dietary protein should not be intakes of protein that promote excessive production of urea and higher than necessary oxidative losses of amino acids than those needed for 'optimal' functioning, as defined above. Why is this? Why not simply consume lots of protein 'just to make sure you're getting enough?' The simple argument is that ultimately nitrogen is still toxic to mammalian metabolic systems and cannot be stored or amino acid pool sizes expanded ad infinitum to accommodate 'extra' amino acids; although there does appear to be some unexplained capacity for this. Consequently, nitrogen consumed in excess of that which is immediately required to support the 'optimal' rates of amino acid utilizing functions outlined above will ultimately result in urea production, and oxidation of the resulting carbon skeletons. It is important to recognize that protein ingestion when considered in this context needs to be evaluated on a meal-to-meal and not on a daily total intake basis, especially if meals are imbalanced in terms of their protein content, since it is the immediate handling of ingested nitrogen that will influence the rate of urea production and amino acid oxidation. It is worthwhile noting that Cuthbertson et al. ${ }^{(56)}$ showed that an ingested dose of $10 \mathrm{~g}$ of essential amino acids maximally stimulated muscle protein synthesis in both the young and the elderly. Since it appears that only dietary essential amino acids are required to maximally stimulate muscle protein synthesis ${ }^{(57,58)}$, these data $^{(56)}$ warrant serious consideration. If we examine the essential amino acid composition of milk proteins, meat, and eggs, then $10 \mathrm{~g}$ of dietary essential amino acids (EAA) translates into $\sim 25 \mathrm{~g}$ of each of these protein sources (most high quality proteins are $\sim 40 \%$ EAA by content), which represents about $\sim 750 \mathrm{ml}$ of skim (non-fat) milk, $4-5$ eggs, or $\sim 100 \mathrm{~g}$ of cooked lean beef. If we were to use these data and assume that a similar anabolic response occurs after each meal, and that muscle protein synthesis is increased and then decreased within $4 \mathrm{~h}$ of consuming a meal ${ }^{(59)}$, one could consume such a meal 4-5 times daily at most. This eating pattern translates into a minimum daily protein intake of $100-125 \mathrm{~g}$ to achieve the 'maximal' muscle anabolic response. Furthermore, we have data showing that the dose of protein required to maximally stimulate muscle and albumin protein synthesis after an isolated bout of resistance exercise is similar (or possibly lower at $\sim 8.5 \mathrm{~g}$ EAA or $\sim 20 \mathrm{~g}$ protein) to that seen at rest $^{(47)}$. Thus, from the standpoint of maximally stimulating muscle protein synthesis a dose of $\sim 20-25 \mathrm{~g}$ of high quality intact protein (such as dairy, egg, or lean meat) appears sufficient. What is missing from these data, however, is knowledge of how the other amino acid requiring processes, underscoring an 'optimal' protein intake, are stimulated by this dose of protein. Ultimately, the answer to the question of how much protein is optimal is difficult to answer. Thus, a default position of many athletes is to consume very large amounts of 
protein in the hope that this will be more than enough to satisfy the myriad of physiological processes that require dietary protein but in effect will do them little harm from an overall health perspective. The potential for a chronically high protein containing diet to influence the metabolic fate of dietary amino acids requires consideration. For example, habitual consumption of a high $(1.8 \mathrm{~g} / \mathrm{kg} / \mathrm{d})$ protein diet increases leucine oxidation at rest and during moderate exercise ${ }^{(60)}$, demonstrating that the body adapts to relatively high protein loads by increasing the capacity for amino acid (or at least leucine) catabolism. In addition, the post-exercise increase in muscle protein synthesis was the lowest in runners consuming a high $(3.6 \mathrm{~g} / \mathrm{kg} / \mathrm{d})$ versus medium $(1.8 \mathrm{~g} / \mathrm{kg} / \mathrm{d})$ or lower $(0.8 \mathrm{~g} / \mathrm{kg} / \mathrm{d})$ protein intakes ${ }^{(55)}$; however, the authors also noted a greater suppression of post-exercise proteolysis when the runners were on a high protein diet. Since the pathways for oxidative amino acid catabolism adapt to the diet and, it has been argued, may act as the main regulator of protein stores ${ }^{(61-63)}$, it is likely that the habitual consumption of a high protein diet means the athlete is 'locked into' consuming greater protein intakes so that fed state gains can balance fasted state losses ${ }^{(63,64)}$. From the standpoint of dietary sources of protein, the consumption of large amounts is likely to have little impact on an athlete's long-term health (see below). Whether such protein intakes affect athletic performance, however, is debatable. In the absence of an UL for protein ${ }^{(1)}$, should athletes, dietitians, coaches, or health care providers be concerned about protein intakes in excess of two times the RDA? The operative question is really when do high protein intakes become 'excessive' and what are the risks? One definition of excess protein is no more than $35 \%$ of an individual's daily energy from protein, if the AMDR guidelines are followed ${ }^{(1)}$

\section{Athletes and dietary protein: too much of a good thing?}

Dietary surveys of athletes, particularly of strength/power training athletes and bodybuilders, indicate that it is not abnormal to see dietary protein intakes in the $2-2.5 \mathrm{~g}$ protein $/ \mathrm{kg} / \mathrm{d}$ range and up to as high as $3.5 \mathrm{~g}$ protein $/ \mathrm{kg} / \mathrm{d}$ (reviewed in ${ }^{(5)}$ ). Protein intakes are not normally as high in endurance trained athletes, usually falling in the range of $1.2-1.6 \mathrm{~g}$ protein $/ \mathrm{kg} / \mathrm{d}$ (reviewed $\mathrm{in}^{(7)}$ ) and tending to be lower in endurance trained women ${ }^{(65-68)}$. Hence, as a general rule it appears that the strength/power athlete and bodybuilders would be more 'at risk' for excessive protein intakes.

If taken to extremes higher dietary protein intakes would, unless weight gain is a desired goal, have to displace another dietary macronutrient. If it is displacement of dietary lipid, then the outcomes are not likely to be of great concern. If, however, the increased consumption of dietary protein results in a lower dietary carbohydrate intake then performance could be compromised. This may be a situation of greater concern if the athlete has voluntarily assumed an energy deficit to change their body weight/body composition as mentioned. This situation would, of course, be exacerbated by dietary energy restriction.
To restore glycogen during high intensity/volume training (i.e., 2-3 training sessions per day), estimated carbohydrate requirements for athletes have ranged from as little as $3-5 \mathrm{~g}$ carbohydrate $/ \mathrm{kg} / \mathrm{d}$ up to as high as $8-10 \mathrm{~g}$ carbohydrate $/ \mathrm{kg} / \mathrm{d}$. It is unlikely, at least at the very high end of the suggested carbohydrate intakes, that any athlete other than highly competitive triathletes, runners, or cyclists would require such intakes to sufficiently maintain the ability to train and perform. Thus, when would lower carbohydrate intakes begin to compromise performance, and at what specific level? The answer is likely to be sport- and trainingspecific; however, it needs to be stressed that even high intensity short-duration muscular efforts (i.e., sprinting and lifting) would rely heavily on carbohydrate ${ }^{(69-73)}$. Given that resistance training/power lifting athletes tend to consume higher protein intakes, such individuals may be at greater risk for lower than optimal carbohydrate intakes to support the most intense training effort possible. Data from MacDougall et $a l .{ }^{(69)}$ showed that with 3 sets of biceps curls (8-10 reps per set) performed at a weight providing $80 \%$ of the subjects' single repetition maximum load (1 RM), muscle glycogen concentration is reduced by almost $35 \%$ from starting levels. Similar results have been obtained by others ${ }^{(71-73)}$. These results provide some support for the idea that carbohydrate is an important and potentially limiting substrate even during resistance exercise workouts ${ }^{(70,73,74)}$. Nevertheless, from a practical standpoint athletes need to consider, in a sport-specific manner, their post-exercise carbohydrate intake, in addition to their protein intake, to optimize performance.

From a health standpoint the response often given is the potential for high protein intakes to result in reduced peak bone mass and impaired renal function. Contradicting those arguments is the knowledge that certain populations consume more protein than the RDA, up to $3.0 \mathrm{~g}$ protein $/ \mathrm{kg} /$ day, without apparent negative health effects, at least not those related to dietary protein. For example, the Northern Canadian and Alaskan Inuit have extraordinarily high protein intakes throughout their lives ${ }^{(75-78)}$. Based on estimated energy intakes that match an expenditure of twice the basal metabolic rate for a male athlete at a high level of training, an intake of $3.0 \mathrm{~g}$ protein $/ \mathrm{kg}$ translates into an overall protein: energy ratio in the diet of $34 \%$, or very close to the highest end of the AMDR in terms of protein, which is currently $35 \%$.

Insofar as protein intake and bone are concerned, there are some studies that have shown increased calciuria with higher protein intakes and a subsequent increased risk for bone fracture or osteoporosis ${ }^{(79)}$; however, several studies now exist supporting a contrary position ${ }^{(80,81)}$. In fact, the relationship between protein intake and bone health has recently been highlighted to be a positive one; that is, the more dietary protein consumed the greater the peak bone mass achieved (reviewed in $\left.^{(82)}\right)$. The mechanism underpinning the greater bone mass with higher intakes of dietary protein appears to be mediated through levels of IGF-1 ${ }^{(82)}$. Increased protein intake may also interact with the high forces generated during resistive type activities, which are potent stimuli for increasing IGF-I (both systemically and locally $)^{(83-85)}$, to further increase peak 
bone mass. Thus, as a health-related reason for why high dietary protein levels might be deleterious for athletes or for the entire population in general, reduced peak bone mass appears to be a dubious argument at best.

Increased risk for the development of renal disease is also an often stated consequence of persistently high dietary protein intakes. Protein can form up to $35 \%$ of dietary energy (as reflected in the AMDR), which would almost certainly provide the RDA and likely much more, unless very low amounts of energy were being consumed. In establishing the RDA, the IOM report reviewed the question of high protein intake on renal disease and concluded that levels of dietary protein are not related to progressive decline in kidney function with age ${ }^{(1)}$. The notion that protein restricted diets decrease the risk of developing kidney disease in the general population is not supported by the scientific literature and, in fact, preliminary studies show a positive effect of higher protein diets on risk factors for kidney disease, including obesity, hypertension, and diabetes ${ }^{(86-90)}$. A review by Bernstein and colleagues $^{(91)}$ compared the effects of animal and vegetable proteins on kidney function. In short term clinical trials, egg white, dairy, and soya consumption did not affect renal function. The researchers noted that "From these studies, it is difficult to conclude whether or not there is a long-term association between amount of animal or vegetable protein intake and change in normal renal function." ${ }^{(91)}$ Hence, it is difficult to make a convincing argument against higher protein intakes for persons with normal renal function, at least in terms of adverse health consequences.

\section{The impact of energy intake}

A discussion of protein 'requirements' and 'optimal' protein intakes for athletes would be incomplete without a discussion of the impact of dietary energy intake; thus, consideration of this topic is given here. Assuming energy balance is a desired goal, an increased energy intake is needed to balance exercising energy expenditure; nevertheless, additional protein intake need not be overly high to achieve nitrogen balance. This is particularly true if the increased energy comes from carbohydrate $^{(92)}$, which owing to the ability of this substrate to stimulate insulin release can markedly suppress proteolysis, consequently improving nitrogen balance ${ }^{(93,94)}$. However, as previously stated, most athletes are not seeking nitrogen balance (i.e., simply getting enough protein to offset nitrogen loss) but instead are looking for an optimal protein intake. It is worth noting that, even in the complete absence of protein intake following exercise, leg muscle protein balance can be brought to levels not different from zero (i.e., no net loss or gain of proteins) simply with the ingestion of carbohydrates alone ${ }^{(93,94)}$.

In a previous review ${ }^{(6)}$, we examined studies that had shown a marked fat loss and a simultaneous 'sparing' of muscle mass through induction of an energy deficit with varying macronutrient ratios. Without going into the same degree of detailed review here we direct the reader to a meta-analysis showing that during hypoenergetic periods it appears that lower carbohydrate (less than $40 \%$ of total energy) and higher protein $(>1.05 \mathrm{~g} / \mathrm{kg} / \mathrm{d})$ intakes result in increased fat mass loss and lean mass preservation, compared to diets higher in carbohydrate and lower in protein ${ }^{(95)}$. In addition, Layman et al. ${ }^{(96)}$ showed that a hypoenergetic diet containing lower carbohydrate and higher protein (carbohydrate-toprotein ratio of 1.6 ) combined with the addition of primarily endurance, but also some resistive, exercise appeared to be the most effective strategy for promoting fat loss and preserving lean mass. This finding may not be surprising when one considers that endurance exercise (to a small degree) ${ }^{(32,33)}$, and resistance exercise (to a large degree) ${ }^{(39,97)}$, are anabolic in that they stimulate muscle protein synthesis even in the fasted state, forcing an increased net 'conservation' of amino acids arising from proteolysis. From an athlete's perspective, however, the important point is that for most sports it is recognized that a higher lean: fat body composition can translate into a competitive advantage. Thus, we concluded previously ${ }^{(6)}$ that a lower carbohydrate, higher protein hypoenergetic diet, particularly when combined with exercise, is likely of substantial benefit for athletes if they wish to attain the associated performance advantage of modifying their body composition by losing stored body fat as opposed to muscle mass ${ }^{(98,99)}$. Of course, such a strategy is not without the obvious limitation that a lower carbohydrate intake in athletes will result in lower muscle glycogen stores ${ }^{(9,10,100)}$. Thus, athletes who adhere to a lower carbohydrate and higher protein diet may be depriving themselves of the fuel that is by far the preferred substrate to power muscular contraction; reviewed in ${ }^{(9,10,100)}$. Clearly, body composition change needs to occur in the lead-up to an athlete's competitive season so as to not adversely affect performance.

\section{Timing of protein consumption and exercise}

When it comes to the stimulation of new muscle protein accretion via resistance exercise it appears that immediate postexercise protein supplementation is beneficial. A review of studies in which protein was given to subjects post-exercise, as a supplement, appears to agree with a general statement that the timing of protein consumption post-exercise may be a determinant of muscle mass and strength gains. Although acute studies suggest that muscle is sensitive to the provision of nutrients (especially amino acids) for up to $3 \mathrm{~h}$ after resistance exercise ${ }^{(43)}$, longitudinal training studies suggest that increases in strength and muscle mass are greatest when protein is consumed immediately after exercise ${ }^{(101-104)}$. In addition, strength and muscle mass gains in patients who had just undergone knee surgery were promoted to a greater degree by protein and carbohydrate consumption than simply carbohydrate or a placebo ${ }^{(101)}$. Gains in muscle fibre size were seen with young men training for 14 weeks only if they consumed protein post-exercise versus isoenergetic carbohydrate ${ }^{(102)}$. Cribb and Hayes ${ }^{(105)}$ reported that a creatine and protein containing supplement consumed immediately prior to and after exercise resulted in greater lean mass gains, strength, and type II muscle fibre area than seen in a 
group who got the same supplement but at different times of the day. We reported that in groups of young men ${ }^{(104)}$ and women $^{(106)}$ that immediate post-exercise consumption either skim milk, the equivalent amount of protein as soya, or isoenergetic carbohydrate after resistance exercise, the greatest lean mass gains were seen in the milk-supplemented group versus both the soya and carbohydrate supplemented groups $^{(104)}$. Hence, it is proposed that our data ${ }^{(104,106)}$, taken together with previous data from chronic studies manipulating post-exercise protein consumption ${ }^{(101-103,105)}$, support the general thesis that immediate consumption of protein, particularly milk protein ${ }^{(104)}$, after resistance exercise serves to maximize exercise-induced increases in muscle mass. Furthermore, consumption of energy in the form of carbohydrate after a resistance exercise workout, when ingested without protein, results in lower resistance exercise-induced gains in muscle mass when compared to protein ${ }^{(104,106)}$.

\section{Practical recommendations}

To attain peak levels of performance, athletes clearly need to be aware of their dietary intake of protein, as well as carbohydrate and a number of other micronutrients and minerals. Highly detailed and refined guidelines for intakes, however, are likely to be confusing for most athletes. Notwithstanding, it appears that emerging dietary guidelines for protein are in the range of $1.2-1.6 \mathrm{~g}$ protein $/ \mathrm{kg} / \mathrm{d}$. This level is greater than the RDA, with the general recommendation that the RDA is a protein intake designed simply to alleviate deficiency. More importantly, it is an intake that appears, based on experimental evidence (mostly nitrogen balance), to be more than sufficient. Should athletes aim to meet or consume higher than this intake? Quite simply, in the absence of evidence that suggests higher intakes are beneficial, it is not yet possible to say that protein intakes higher than those suggested will be beneficial. What appears to be critical, as with the recommendations for carbohydrate, however, is that the timing of ingestion is very important. Put simply, protein should be consumed early during the post-exercise recovery phase (i.e., immediately to $2 \mathrm{~h}$ after exercise). Protein quality also appears to be important in maximizing the accretion of muscle proteins, so athletes would do well to focus on high quality protein sources such as dairy protein, eggs, and lean meat. When athletes find it inconvenient to consume such protein sources then portable protein sources, particularly protein supplements, offer a practical alternative. The content of these protein supplements should be closely scrutinized by athletes for quality, however, since protein bars and drinks are highly heterogeneous in terms of their composition. The high quality protein dose that appears to maximally stimulate muscle protein synthesis is close to $20-25 \mathrm{~g}$, above which protein synthesis is not additionally stimulated but increases in amino acid oxidation and urea synthesis may result.

As a closing remark, it is tempting to dismiss the notion of protein intakes for athletes as relatively unimportant since all athletes appear to consume enough protein; however, adequate protein consumption is not always the case, particularly when female athletes are concerned. More importantly, athletes, dieticians and coaches alike would be remiss in their attention to detail to simply tell athletes that they get enough protein and that there is nothing more that they have to be concerned about. As noted by Burke et al. ${ }^{(10)}$, dietary guidelines for athletes are unanimous in their recommendation of high carbohydrate intakes for enhancing performance and yet many top athletes do not appear to achieve the levels of carbohydrate recommended. Quoting the authors of the same article ${ }^{(10)}$, "The... failure of these athletes to achieve the daily $\mathrm{CHO}$ [and also protein] intakes recommended by sports nutritionists does not necessarily invalidate the benefits of meeting such guidelines". Thus, hidden in the details of the recommended guidelines for protein intakes for athletes are points regarding timing, composition (quality), as well as consumption in combination with macronutrients such as carbohydrate. Attention to these details, it is contended, will allow athletes to perform to the best of their potential.

\section{Acknowledgements}

The paper was conceived, written, and responsibility for final content rests with the author (SMP). The author states that there are no conflicts of interest. This research received no specific grant from any funding agency in the public, commercial or not-for-profit sectors.

\section{References}

1. Institute of Medicine (2005) Dietary Reference Intakes for energy, carbohydrate, fiber, fat, fatty acids, cholesterol, protein, and amino acids. Washington, DC: National Academies Press.

2. Rodriguez NR, Di Marco NM \& Langley S (2009) American College of Sports Medicine position stand. Nutrition and athletic performance. Med Sci Sports Exerc 41, 709-731.

3. WHO Technical Report Series 935. Protein and Amino Acid Requirements in Human Nutrition: report of a joint FAO/ WHO/UNU expert consultation. Report of a JointWHO/ FAO/UNU Expert Consultation. 2011.

4. Phillips SM, Hartman JW \& Wilkinson SB (2005) Dietary protein to support anabolism with resistance exercise in young men. J Am Coll Nutr 24, 134S-139S.

5. Phillips SM (2004) Protein requirements and supplementation in strength sports. Nutrition 20, 689-695.

6. Phillips SM (2006) Dietary protein for athletes: from requirements to metabolic advantage. App Physiol Nutr Metab 31, 647-654

7. Tarnopolsky MA (2004) Protein requirements for endurance athletes. Nutrition 20, 662-668.

8. Rennie MJ \& Tipton KD (2000) Protein and amino acid metabolism during and after exercise and the effects of nutrition. Annu Rev Nutr 20, 457-483.

9. Burke LM (2001) Energy needs of athletes. Can J Appl Physiol 26, S202-S219.

10. Burke LM, Cox GR, Culmmings NK, et al. (2001) Guidelines for daily carbohydrate intake: do athletes achieve them? Sports Med 31, 267-299. 
11. Burke LM, Kiens B \& Ivy JL (2004) Carbohydrates and fat for training and recovery. J Sports Sci 22, 15-30.

12. Burke LM, Millet G \& Tarnopolsky MA (2007) Nutrition for distance events. J Sports Sci 25, Suppl. 1, S29-S38.

13. Biolo G, Ciocchi B, Stulle M, et al. (2007) Calorie restriction accelerates the catabolism of lean body mass during $2 \mathrm{wk}$ of bed rest. Am J Clin Nutr 86, 366-372.

14. Biolo G, Agostini F, Simunic B, et al. (2008) Positive energy balance is associated with accelerated muscle atrophy and increased erythrocyte glutathione turnover during $5 \mathrm{wk}$ of bed rest. Am J Clin Nutr 88, 950-958.

15. Astrup A, Dyerberg J, Elwood P, et al. (2011) The role of reducing intakes of saturated fat in the prevention of cardiovascular disease: where does the evidence stand in 2010? Am J Clin Nutr 93, 684-688.

16. Rand WM, Pellett PL \& Young VR (2003) Meta-analysis of nitrogen balance studies for estimating protein requirements in healthy adults. Am J Clin Nutr 77, 109-127.

17. Millward DJ \& Rivers JP (1988) The nutritional role of indispensable amino acids and the metabolic basis for their requirements. Eur J Clin Nutr 42, 367-393.

18. Millward DJ \& Rivers JP (1989) The need for indispensable amino acids: the concept of the anabolic drive. Diabetes Metab Rev 5, 191-211.

19. Babraj J, Cuthbertson DJ, Rickhuss P, et al. (2002) Sequential extracts of human bone show differing collagen synthetic rates. Biochem Soc Trans 30, 61-65.

20. Babraj JA, Smith K, Cuthbertson DJ, et al. (2005) Human bone collagen synthesis is a rapid, nutritionally modulated process. J Bone Miner Res 20, 930-937.

21. Heinemeier K, Langberg H, Olesen JL, et al. (2003) Role of TGF-beta1 in relation to exercise-induced type I collagen synthesis in human tendinous tissue. J Appl Physiol 95, 2390-2397.

22. Rennie MJ, Wackerhage H, Spangenburg EE, et al. (2004) Control of the size of the human muscle mass. Annu Rev Physiol 66, 799-828.

23. Nakshabendi IM, McKee R, Downie S, et al. (1999) Rates of small intestinal mucosal protein synthesis in human jejunum and ileum. Am J Physiol 277, E1028-E1031.

24. Nakshabendi IM, Obeidat W, Russell RI, et al. (1995) Gut mucosal protein synthesis measured using intravenous and intragastric delivery of stable tracer amino acids. $A m$ J Physiol 269, E996-E999.

25. Young VR (1986) Nutritional balance studies: indicators of human requirements or of adaptive mechanisms? J Nutr 116, 700-703.

26. Young VR, Wayler A, Garza C, et al. (1984) A long-term metabolic balance study in young men to assess the nutritional quality of an isolated soy protein and beef proteins. Am J Clin Nutr 39, 8-15.

27. McKenzie S, Phillips SM, Carter SL, et al. (2000) Endurance exercise training attenuates leucine oxidation and BCOAD activation during exercise in humans. Am J Physiol Endocrinol Metab 278, E580-E587.

28. Phillips SM, Atkinson SA, Tarnopolsky MA, et al. (1993) Gender differences in leucine kinetics and nitrogen balance in endurance athletes. J Appl Physiol 75, 2134-2141.

29. Lamont LS, McCullough AJ \& Kalhan SC (1999) Comparison of leucine kinetics in endurance-trained and sedentary humans. J Appl Physiol 86, 320-325.

30. Lamont LS, McCullough AJ \& Kalhan SC (2001) Relationship between leucine oxidation and oxygen consumption during steady-state exercise. Med Sci Sports Exerc 33, $237-241$.
31. Lamont LS, McCullough AJ \& Kalhan SC (2001) Gender differences in leucine, but not lysine, kinetics. J Appl Physiol 91, 357-362.

32. Miller BF, Olesen JL, Hansen M, et al. (2005) Coordinated collagen and muscle protein synthesis in human patella tendon and quadriceps muscle after exercise. $J$ Physiol 567, 1021-1033.

33. Sheffield-Moore M, Yeckel CW, Volpi E, et al. (2004) Post exercise protein metabolism in older and younger men following moderate-intensity aerobic exercise. $\mathrm{Am}$ J Physiol Endocrinol Metab 287, E513-E522.

34. Carraro F, Stuart CA, Hartl WH, et al. (1990) Effect of exercise and recovery on muscle protein synthesis in human subjects. Am J Physiol 259, E470-E476.

35. Hartman JW, Moore DR \& Phillips SM (2006) Resistance training reduces whole-body protein turnover and improves net protein retention in untrained young males. Appl Physiol Nutr Metab 31, 557-564.

36. Moore DR, Del Bel NC, Nizi KI, et al. (2007) Resistance training reduces fasted- and fed-state leucine turnover and increases dietary nitrogen retention in previously untrained young men. J Nutr 137, 985-991.

37. Butterfield GE \& Calloway DH (1984) Physical activity improves protein utilization in young men. Br J Nutr $\mathbf{5 1}$, $171-184$.

38. Todd KS, Butterfield GE \& Calloway DH (1984) Nitrogen balance in men with adequate and deficient energy intake at three levels of work. J Nutr 114, 2107-2118.

39. Phillips SM, Tipton KD, Aarsland A, et al. (1997) Mixed muscle protein synthesis and breakdown after resistance exercise in humans. Am J Physiol 273, E99-E107.

40. Millward DJ \& Jackson AA (2004) Protein/energy ratios of current diets in developed and developing countries compared with a safe protein/energy ratio: implications for recommended protein and amino acid intakes. Public Health Nutr 7, 387-405.

41. Burd NA, Tang JE, Moore DR, et al. (2009) Exercise training and protein metabolism: influences of contraction, protein intake, and sex-based differences. J Appl Physiol 106, 1692-1701.

42. Miller SL, Tipton KD, Chinkes DL, et al. (2003) Independent and combined effects of amino acids and glucose after resistance exercise. Med Sci Sports Exerc 35, 449-455.

43. Rasmussen BB, Tipton KD, Miller SL, et al. (2000) An oral essential amino acid-carbohydrate supplement enhances muscle protein anabolism after resistance exercise. $J A p p l$ Physiol 88, 386-392.

44. Tipton KD, Ferrando AA, Phillips SM, et al. (1999) Postexercise net protein synthesis in human muscle from orally administered amino acids. Am J Physiol 276, E628-E634.

45. Tipton KD, Rasmussen BB, Miller SL, et al. (2001) Timing of amino acid-carbohydrate ingestion alters anabolic response of muscle to resistance exercise. Am J Physiol Endocrinol Metab 281, E197-E206.

46. Tipton KD, Elliott TA, Cree MG, et al. (2004) Ingestion of casein and whey proteins result in muscle anabolism after resistance exercise. Med Sci Sports Exerc 36, 2073-2081.

47. Moore DR, Robinson MJ, Fry JL, et al. (2009) Ingested protein dose response of muscle and albumin protein synthesis after resistance exercise in young men. Am J Clin Nutr $\mathbf{8 9}$, $161-168$.

48. Tipton KD \& Wolfe RR (2001) Exercise, protein metabolism, and muscle growth. Int $J$ Sport Nutr Exerc Metab 11, 109-132.

49. Wolfe RR (2000) Protein supplements and exercise. Am J Clin Nutr 72, 551S-557S. 
50. Friedman JE \& Lemon PW (1989) Effect of chronic endurance exercise on retention of dietary protein. Int J Sports Med 10, 118-123

51. Reeds PJ \& Garlick PJ (2003) Protein and amino acid requirements and the composition of complementary foods. J Nutr 133, 2953S-2961S.

52. Anthony JC, Anthony TG, Kimball SR, et al. (2001) Signaling pathways involved in translational control of protein synthesis in skeletal muscle by leucine. J Nutr 131, $856 \mathrm{~S}-860 \mathrm{~S}$

53. Anthony JC, Yoshizawa F, Anthony TG, et al. (2000) Leucine stimulates translation initiation in skeletal muscle of postabsorptive rats via a rapamycin-sensitive pathway. J Nutr 130, 2413-2419.

54. Anthony JC, Reiter AK, Anthony TG, et al. (2002) Orally administered leucine enhances protein synthesis in skeletal muscle of diabetic rats in the absence of increases in 4E-BP1 or S6K1 phosphorylation. Diabetes 51, 928-936.

55. Bolster DR, Pikosky MA, Gaine PC, et al. (2005) Dietary protein intake impacts human skeletal muscle protein fractional synthetic rates after endurance exercise. $A m$ $J$ Physiol Endocrinol Metab 289, E678-E683.

56. Cuthbertson D, Smith K, Babraj J, et al. (2005) Anabolic signaling deficits underlie amino acid resistance of wasting, aging muscle. FASEB J 19, 422-424.

57. Tipton KD, Gurkin BE, Matin S, et al. (1999) Non essential amino acids are not necessary to stimulate net muscle protein synthesis in healthy volunteers. J Nutr Biochem 10, 89-95.

58. Volpi E, Kobayashi H, Sheffield-Moore M, et al. (2003) Essential amino acids are primarily responsible for the amino acid stimulation of muscle protein anabolism in healthy elderly adults. Am J Clin Nutr 78, 250-258.

59. Moore DR, Tang JE, Burd NA, et al. (2009) Differential stimulation of myofibrillar and sarcoplasmic protein synthesis with protein ingestion at rest and after resistance exercise. J Physiol 597, 897-904.

60. Bowtell JL, Leese GP, Smith K, et al. (1998) Modulation of whole body protein metabolism, during and after exercise, by variation of dietary protein. $J$ Appl Physiol 85, $1744-1752$.

61. Millward DJ (2004) Macronutrient intakes as determinants of dietary protein and amino acid adequacy. $J$ Nutr 134, 1588S-1596S

62. Millward DJ (1998) Metabolic demands for amino acids and the human dietary requirement: Millward and Rvers (1988) revisited. J Nutr 128, 2563S-2576S

63. Quevedo MR, Price GM, Halliday D, et al. (1994) Nitrogen homoeostasis in man: diurnal changes in nitrogen excretion, leucine oxidation and whole body leucine kinetics during a reduction from a high to a moderate protein intake. Clin Sci (Lond) 86, 185-193.

64. Price GM, Halliday D, Pacy PJ, et al. (1994) Nitrogen homeostasis in man: influence of protein intake on the amplitude of diurnal cycling of body nitrogen. Clin Sci (Lond) 86, 91-102.

65. Deuster PA, Kyle SB, Moser PB, et al. (1986) Nutritional survey of highly trained women runners. Am J Clin Nutr 44, 954-962.

66. Singh A, Deuster PA, Day BA, et al. (1990) Dietary intakes and biochemical markers of selected minerals: comparison of highly trained runners and untrained women. J Am Coll Nutr 9, 65-75.

67. Snead DB, Stubbs CC, Weltman JY, et al. (1992) Dietary patterns, eating behaviors, and bone mineral density in women runners. Am J Clin Nutr 56, 705-711.
68. Beals KA \& Manore MM (1998) Nutritional status of female athletes with subclinical eating disorders. J Am Diet Assoc 98, 419-425.

69. MacDougall JD, Ray S, Sale DG, et al. (1999) Muscle substrate utilization and lactate production. Can J Appl Physiol 24, 209-215.

70. Lambert CP \& Flynn MG (2002) Fatigue during highintensity intermittent exercise: application to bodybuilding. Sports Med 32, 511-522.

71. Robergs RA, Pearson DR, Costill DL, et al. (1991) Muscle glycogenolysis during differing intensities of weight-resistance exercise. J Appl Physiol 70, 1700-1706.

72. Essen-Gustavsson B \& Tesch PA (1990) Glycogen and triglyceride utilization in relation to muscle metabolic characteristics in men performing heavy-resistance exercise. Eur J Appl Physiol Occup Physiol 61, 5-10.

73. Tesch PA, Colliander EB \& Kaiser P (1986) Muscle metabolism during intense, heavy-resistance exercise. Eur J Appl Physiol Occup Physiol 55, 362-366.

74. Haff GG, Lehmkuhl MJ, McCoy LB, et al. (2003) Carbohydrate supplementation and resistance training. J Strength Cond Res 17, 187-196.

75. Kuhnlein HV \& Receveur O (2007) Local cultural animal food contributes high levels of nutrients for Arctic Canadian Indigenous adults and children. J Nutr 137, 1110-1114.

76. Kuhnlein HV, Soueida R \& Receveur O (1996) Dietary nutrient profiles of Canadian Baffin Island Inuit differ by food source, season, and age. J Am Diet Assoc 96, 155-162.

77. Risica PM, Nobmann ED, Caulfield LE, et al. (2005) Springtime macronutrient intake of Alaska natives of the Bering Straits Region: the Alaska Siberia Project. Int J Circumpolar Health 64, 222-233.

78. Nobmann ED, Byers T, Lanier AP, et al. (1992) The diet of Alaska Native adults: 1987-1988. Am J Clin Nutr 55, 1024-1032.

79. Feskanich D, Willett WC, Stampfer MJ, et al. (1996) Protein consumption and bone fractures in women. Am J Epidemiol 143, 472-479.

80. Wengreen HJ, Munger RG, West NA, et al. (2004) Dietary protein intake and risk of osteoporotic hip fracture in elderly residents of Utah. J Bone Miner Res 19, 537-545.

81. Munger RG, Cerhan JR \& Chiu BC (1999) Prospective study of dietary protein intake and risk of hip fracture in postmenopausal women. Am J Clin Nutr 69, 147-152.

82. Bonjour JP (2005) Dietary protein: an essential nutrient for bone health. I Am Coll Nutr 24, 526S-536S.

83. Bamman MM, Shipp JR, Jiang J, et al. (2001) Mechanical load increases muscle IGF-I and androgen receptor mRNA concentrations in humans. Am J Physiol Endocrinol Metab 280, E383-E390.

84. Hameed M, Orrell RW, Cobbold M, et al. (2003) Expression of IGF-I splice variants in young and old human skeletal muscle after high resistance exercise. J Physiol 547, 247-254.

85. Nindl BC, Kraemer WJ, Marx JO, et al. (2001) Overnight responses of the circulating IGF-I system after acute, heavy-resistance exercise. J Appl Physiol 90, 1319-1326.

86. Layman DK, Boileau RA, Erickson DJ, et al. (2003) A reduced ratio of dietary carbohydrate to protein improves body composition and blood lipid profiles during weight loss in adult women. $J$ Nutr 133, 411-417.

87. Layman DK, Shiue H, Sather C, et al. (2003) Increased dietary protein modifies glucose and insulin homeostasis in adult women during weight loss. J Nutr 133, 405-410.

88. Zemel MB (2003) Mechanisms of dairy modulation of adiposity. J Nutr 133, 252S-256S. 
89. Zemel MB, Thompson W, Milstead A, et al. (2004) Calcium and dairy acceleration of weight and fat loss during energy restriction in obese adults. Obes Res 12, 582-590.

90. Pins JJ \& Keenan JM (2006) Effects of whey peptides on cardiovascular disease risk factors. J Clin Hypertens (Greenwich) 8, 775-782.

91. Bernstein AM, Treyzon L \& Li Z (2007) Are high-protein, vegetable-based diets safe for kidney function? A review of the literature. J Am Diet Assoc 107, 644-650.

92. Richardson DP, Wayler AH, Scrimshaw NS, et al. (1979) Quantitative effect of an isoenergetic exchange of fat for carbohydrate on dietary protein utilization in healthy young men. Am J Clin Nutr 32, 2217-2226.

93. Borsheim E, Cree MG, Tipton KD, et al. (2004) Effect of carbohydrate intake on net muscle protein synthesis during recovery from resistance exercise. J Appl Physiol 96, 674-678.

94. Chow LS, Albright RC, Bigelow ML, et al. (2006) Mechanism of insulin's anabolic effect on muscle: measurements of muscle protein synthesis and breakdown using aminoacyl-tRNA and other surrogate measures. Am J Physiol Endocrinol Metab 291, E729-E736.

95. Krieger JW, Sitren HS, Daniels MJ, et al. (2006) Effects of variation in protein and carbohydrate intake on body mass and composition during energy restriction: a metaregression. Am J Clin Nutr 83, 260-274.

96. Layman DK, Evans E, Baum JI, et al. (2005) Dietary protein and exercise have additive effects on body composition during weight loss in adult women. J Nutr 135, 1903-1910.

97. Phillips SM, Tipton KD, Ferrando AA, et al. (1999) Resistance training reduces the acute exercise-induced increase in muscle protein turnover. Am J Physiol 276, E118-E124.
98. Mettler S, Mitchell N \& Tipton KD (2010) Increased protein intake reduces lean body mass loss during weight loss in athletes. Med Sci Sports Exerc 42, 326-337.

99. Pikosky MA, Smith TJ, Grediagin A, et al. (2008) Increased protein maintains nitrogen balance during exercise-induced energy deficit. Med Sci Sports Exerc 40, 505-512.

100. Burke LM, Kiens B \& Ivy JL (2004) Carbohydrates and fat for training and recovery. J Sports Sci 22, 15-30.

101. Holm L, Esmarck B, Mizuno M, et al. (2006) The effect of protein and carbohydrate supplementation on strength training outcome of rehabilitation in ACL patients. J Orthop Res 24, 2114-2123.

102. Andersen LL, Tufekovic G, Zebis MK, et al. (2005) The effect of resistance training combined with timed ingestion of protein on muscle fiber size and muscle strength. Metabolism 54, 151-156.

103. Esmarck B, Andersen JL, Olsen S, et al. (2001) Timing of postexercise protein intake is important for muscle hypertrophy with resistance training in elderly humans. J Physiol 535, 301-311.

104. Hartman JW, Tang JE, Wilkinson SB, et al. (2007) Consumption of fat-free fluid milk after resistance exercise promotes greater lean mass accretion than does consumption of soy or carbohydrate in young, novice, male weightlifters. $\mathrm{Am}$ J Clin Nutr 86, 373-381.

105. Cribb PJ \& Hayes A (2006) Effects of supplement timing and resistance exercise on skeletal muscle hypertrophy. Med Sci Sports Exerc 38, 1918-1925.

106. Josse AR, Tang JE, Tarnopolsky MA, et al. (2010) Body composition and strength changes in women with milk and resistance exercise. Med Sci Sports Exerc 42, 1122-1130. 